\title{
Analisis Asuhan Keperawatan Pasien Coronary Artery Disease Pre Coronary Artery Bypass Grafting
}

\author{
Mutarobin $^{1}$, Elly Nurachmah ${ }^{2}$, Muhamad Adam ${ }^{2}$ \\ 1Jurusan Keperawatan Politeknik Kesehatan Jakarta I, Indonesia. \\ ${ }^{2}$ Fakultas Ilmu Keperawatan Universitas Indonesia, Indonesia. \\ email: obien8oke@yahoo.com
}

Submitted: 07-05-2019, Revised: 13-05-2019, Revised: 12-06-2019 Accepted: 20-06-2019

\begin{abstract}
Abstrak
Coronary Artery Disease (CAD) merupakan suatu gangguan fungsi jantung yang disebabkan karena adanya penyempitan dan tersumbatnya pembuluh darah jantung. Kondisi ini dapat mengakibatkan perubahan pada berbagai aspek, baik fisik, psikologis, maupun sosial yang berakibat pada penurunan kapasitas fungsional jantung dan kenyamanan. Peran sebagai pemberi asuhan keperawatan diterapkan pada seorang laki-laki berusia 70 tahun dengan CAD 3VD EF $52 \%$ PRE-CABG X3 OFF PUMP dengan pendekatan Model Adaptasi Roy (MAR). Tujuan dari penelitian adalah untuk mengeksplorasi masalah asuhan keperawatan pada pasien gangguan sistem kardiovaskular. Penelitian ini memakai desain studi kasus dengan pendekatan asuhan keperawatan yang diberikan pada satu orang pasien dengan gangguan sistem kardiovaskular, tidak membatasi umur dan tidak menentukan jenis kelamin yang akan dijadikan dalam sebuah studi kasus di Rumah Sakit Jantung dan Pembuluh Darah Harapan Kita Jakarta. Teknik analisa data dengan cara pengumpulan data dari pengkajian sampai dilakukan evaluasi dan pendokumentasian. Hasil penelitian didapatkan pengkajian perilaku dan stimulus dapat diterapkan lebih optimal pada seting ruang rawat biasa dimana kondisi pasien sudah stabil dan tidak berisiko tinggi mengalami penurunan cardiac output. Penegakan diagnosa keperawatan mengacu pada NANDA dan SDKI. Roy tidak menetapkan intervensi spesifik untuk tiap diagnosa berdasarkan Model Adaptasi Roy yang menjelaskan tentang mekanisme koping pada subsistem regulator dan cognator. Evaluasi keperawatan dianalisis berdasarkan perilaku adaptasi yang dicapai oleh pasien pada keempat mode adaptasi. Teori Model Adaptasi Roy ini dapat diaplikasikan dalam memberikan asuhan keperawatan pada pasien dengan gangguan sistem kardiovaskular dengan menggunakan format yang disesuaikan dengan format yang ada di rumah sakit.
\end{abstract}

Kata Kunci: Model Adaptasi Roy, CAD, CABG

\section{Abstract \\ Nursing Analysis in Disorder Patients With Cardiovascular System Approach The Model of The}

Roy Adaptation Theory. Coronary Artery Disease $(C A D)$ is a function of the heart caused by narrowing and blocked blood vessels. This condition can help changes in various aspects, both physical, psychological, and social which result in a decrease in function and comfort abilities. The role of nursing care provider was applied to 70-year-old men with CAD $3 \mathrm{VD}$ EF 52\% PRE-CABG X3 OFF PUMP by supporting Roy's Adaptation Model (MAR). The purpose of the study was to discuss the problem of nursing care in patients with cardiovascular system disorders. This study uses a case study design with nursing care given to one patient with a cardiovascular system, age disagreement and does not specify the sex to be used in a case study at Harapan Kita Heart and Vascular Hospital, Jakarta. Data analysis techniques by analyzing data from the assessment to evaluation and documentation. The results of the research obtained by policy and stimulus studies can be applied more optimally in the arrangement of ordinary care rooms where patients are stable and not at high risk of reducing cardiac output. Enforcement of attractive nursing diagnoses on NANDA and SDKI. Roy did not arrange specific interventions for each diagnosis based on Roy's Adaptation Model which explained the coping relationships on the regulator and cognator subsystems. Nursing evaluation is completed based on the adaptation achieved by the patient in the mode of adaptation. Roy's Adaptation Model Theory can be used in providing nursing care to patients with cardiovascular system disorders using a format adapted to the format in the hospital.

Keywords: Roy's Adaptation Model, CAD, CABG

\section{Pendahuluan}

Coronary Artery Disease (CAD) merupakan suatu gangguan fungsi jantung yang disebabkan karena otot miokard kekurangan suplai darah akibat adanya penyempitan arteri koroner dan tersumbatnya pembuluh darah jantung (AHA, 2017). Bash (2015) dalam studi Biopsycosocial 
Spiritual Factors Impacting African American Patient's Cardiac Rehabilitation Refferal and Participation menyatakan bahwa sebagian besar dari pasien CAD memiliki historical assessment obesitas (35\%), gaya hidup (30\%), hipertensi (33\%), sindrom metabolik (35\%), pre diabetes melitus $(38,2 \%)$, diabetes melitus $(8,3 \%)$, dan merokok $(20,5 \%)$ laki-laki dan $(15,9 \%)$ wanita berkontribusi pada peningkatan prevalensi Atherosclerotic Cardiovascular Disease (ASCVD). Selain itu, sebagian besar pasien CAD juga memiliki clinical assessment seperti nyeri dada, sesak napas, TD systole < $100-150 \mathrm{mmHg}$, dan dyastole > $90 \mathrm{mmHg}$, denyut nadi dalam rentang $50-90 \mathrm{x} /$ menit, saturasi $\mathrm{O} 2<85 \%$, peningkatan HDL dan LDL, peningkatan enzim jantung Troponin I, Troponin T, dan CK-CKMB (Bash, 2015).

Setiap tahunnya tujuh belas juta orang tutup usia karena penyakit jantung dan pembuluh darah. Sebanyak 7,3 juta diantaranya terjadi akibat penyakit jantung koroner (WHO, 2014). Prevalensi penyakit jantung koroner di Indonesia pada tahun 2018 meningkat secara signifikan menjadi 1,5\% dari yang sebelumya pada tahun 2013 sebanyak $0,13 \%$, dengan prevalensi tertinggi di provinsi Kalimantan Utara yaitu 2,2 \% dari total penduduk semua umur, sedangakan Provinsi DKI Jakarta menduduki peringkat ke-5 (Riskesdas, 2018).

Perawat dalam membantu pasien memenuhi kebutuhan dan derajat kesehatan pasien yang paling optimal, dituntut untuk menjalankan perannya tidak hanya sebagai pemberi asuhan keperawatan kepada pasien, tetapi juga harus menjalankan peran-peran lainnya untuk melengkapi peran utamanya sebagai seorang pemberi asuhan keperawatan. Ignatavicius \& Workman (2010) mengemukakan bahwa perawat yang mengkhususkan diri dalam bidang keperawatan medikal bedah memiliki tanggung jawab untuk menjalankan peran sebagai pemberi asuhan, pendidik, advokat, dan pembaharu atau innovator.
Perawat menjalankan peran sebagai pelaksana atau pemberi asuhan keperawatan, perawat juga sekaligus menjalankan peran kepemimpinannya agar dapat mempengaruhi perubahan perilaku pasien, menerima atau memberikan konsultasi tim perawat dan tim kesehatan lain untuk memenuhi kebutuhan pasien. Perawat juga harus mengembangkan dan mengidentifikasi sumber-sumber pembelajaran bagi pasien dan keluarga serta memberikan pendidikan tentang rencana perawatan yang sedang dijalaninya agar pasien dapat kooperatif dan mempertahankan perilaku yang positif dan adaptif dalam mencapai status kesehatan pasien seoptimal mungkin.

Dalam menjalankan peran ini, perawat diharapakan mampu untuk menerapkan asuhan keperawatan menggunakan pendekatan teori model keperawatan. Teori model keperawatan yang digunakan selama praktik keperawatan ini adalah teori model konseptual adaptasi yang dikembangkan oleh Sister Callista Roy yang diterbitkan pertama kali sejak tahun 1970 dan dikenal dengan Model Adaptasi Roy (MAR). Christensen \& Kenney (2009) mengemukakan bahwa sejak diterbitkannya teori ini, secara kontinyu dilakukan perbaikan dan pengembangan agar dapat diterapkan pada berbagai seting keperawatan. Pendekatan teori Calista Roy Model adaptasi Roy mengkaji respon individu terhadap perubahan yang terjadi pada dirinya secara mendalam sampai pada terbentuknya koping untuk memberikan gambaran suatu proses kontrol sebagai sebuah sistem yang adaptif. Sistem adaptif pada teori Roy digambarkan secara terperinci dengan menerapkan 4 efektor yaitu fisiologis, konsep diri, fungsi peran dan interdependensi. Roy berpendapat bahwa asuhan keperawatan kardiovaskular menitikberatkan pada kemampuan seseorang beradaptasi terhadap masalah yang dihadapi. Sementara perawat dalam hal ini berperan sebagai fasilitator yang mengefektifkan potensi pada diri klien. 
Hasil penelitian sebelumnya yang dilakukan oleh Roy \& Andrews (2009) menyatakan bahwa aplikasi Model Adaptasi Roy dilengkapi dengan penerapan Health Belief Model untuk mengkaji pemahaman klien tentang masalah kesehatan, pemahaman tentang manfaat yang dirasakan dari tindakan yang dilakukan, pemahaman tentang hambatan yang sifatnya negatif untuk melakukan tindakan yang bersangkutan, pemahaan tentang keseriusan penyakit yang dirasakan, modifikasi yang dilakukan berkaitan dengan penyakit yang dialami, dorongan untuk melakukan tindakan dan kemampuan untuk melakukan tindakan. Penerapan dua model keperawatan ini dilakukan dengan harapan selain klien mampu beradaptasi dengan perubahan status kesehatannya klien juga mampu meminimalkan penularan infeksi terhadap janin yang dikandungnya. Sedangkan kelemahan dari model adaptasi Roy ini adalah terletak pada sasarannya. Model adaptasi Roy ini hanya berfokus pada proses adaptasi pasien dan bagaimana pemecahan masalah pasien dengan menggunakan proses keperawatan dan tidak menjelaskan bagaimana sikap dan perilaku cara merawat (caring) pada pasien, sehingga seorang perawat yang tidak mempunyai perilaku caring ini menjadi stressor bagi para pasiennya.

Selama praktik keperawatan, teori RAM ini diterapkan pada pemberian asuhan keperawatan pasien yang mengalami gangguan sistem kardiovaskular. Dalam laporan kegiatan praktik keperawatan ini, sindrom koroner akut diangkat sebagai kasus utama, khsususnya Coronary Artery Disease (CAD) dengan pertimbangan bahwa pendalaman pengetahuan dan pengalaman tentang asuhan keperawatan pada gangguan sistem kardiovaskular ini sangat krusial karena angka prevalensi CAD semakin meningkat dari tahun ke tahun dan menjadi penyebab kematian paling sering pada penderita penyakit jantung.

\section{Metode}

Penelitian ini memakai desain studi kasus dengan pendekatan asuhan keperawatan yaitu penelitian dengan cara mengumpulkan data yang dimulai dari pengkajian, menentukan diagnosis, melakukan perencanaan, melaksanakan tindakan, dan melakukan evaluasi yang diberikan pada satu orang pasien dengan gangguan sistem kardiovaskular, tidak membatasi umur dan tidak menentukan jenis kelamin yang akan dijadikan dalam sebuah studi kasus. Tujuan dari penelitian ini adalah untuk mengeksplorasi masalah asuhan keperawatan dimulai dari pengkajian sampai dengan evaluasi kepada pasien gangguan sistem kardiovaskular. Analisa data dilakukan sejak peneliti melakukan asuhan keperawatan yang dilakukan mulai awal pengkajian dan dilakukan pendokumentasian pada setiap hari untuk mengetahui perkembangan dari pasien. Studi kasus ini telah mendapatkan izin dari FIK UI dan Rumah Sakit Jantung dan Pembuluh Darah Harapan Kita Jakarta.Teknik analisis data yang dipakai oleh peneliti adalah dengan cara pengumpulan data dengan menggunakan cara wawancara dan observasi pada pasien.

\section{Gambaran Kasus}

Seorang laki-laki berumur 70 tahun, status: menikah, pendidikan: SMA, alamat: Jalan Ki Anwar Mangku RT 04/15. Palapa Plaju Palembang, pekerjaan: swasta, agama: islam, No. RM: 2018-43-69-43, tanggal masuk: 05-03-2018, tanggal Pengkajian: 05-03-2018, diagnosa medis: CAD 3VD dengan EF 52\%, dominan kanan, LM stenosis $60 \%$ di distal, LAD stenosis $75 \%$ di proksimal dan $80 \%$ di mid difusse, LCX stenosis $80 \%$ di distal dan osteal OM1 60\%, RCA CTO di proksimal dan kolateral dari LCX.

Keluhan utama, pasien mengatakan sedikit takut untuk menjalani operasi. Saat ini pasien direncanakan untuk operasi bedah jantung (CABG). Pasien dengan riwayat nyeri dada berulang yang menjalar ke lengan kiri, sesak tidak ada, pasien mengatakan cepat lelah saat berkativitas, pasien mengeluh nyeri pada area dada sebelah kiri dengan skala 3-5 (0-10), nyeri terasa pada saat latihan napas dalam dan terutama saat akan batuk. 
Riwayat kesehatan sekarang, tanggal 5 Maret 2018 Pukul 15.00 WIB pasien masuk Ruang IW Bedah rencana untuk dilakukan CABG. Pasien mempunyai riwayat DM, hipertensi, dan merokok. Tanggal 6 Maret 2018 Pukul 12.16 WIB pasien masuk OK untuk dilakukan CABG, saat pengkajian perioperatif didapatkan data tidak ada sesak napas, nyeri dada, pusing, cyanosis. Serah terima rekam medis ada. Tidak ada alat bantu yang terpasang (pacemaker, IABP). Terdapat tanda lahir belang putih di dekat ketiak sebelah kiri. Data hemodinamik awal TD 90/48 mmHg, HR 55 kali/menit, RR 15 kali/menit, suhu $35,8^{\circ} \mathrm{C}$ dan saturasi oksigen $100 \%$.

Riwayat kesehatan dahulu, riwayat mengalami hipertensi, stroke, asma, dan gastritis disangkal oleh pasien. Pasien memiliki riwayat merokok. Riwayat kesehatan keluarga, riwayat keluarga mengalami penyakit jantung disangkal. Dalam keluarga tidak ada yang memiliki riwayat asma, hipertensi, stroke.

Pengkajian perilaku dan stimulus pre operasi meliputi: mode adaptasi fisiologis yaitu oksigenasi. Pengkajian perilaku, subyektif: pasien mengatakan nyeri dada, sesak, dan cepat lelah. Obyektif: batuk tidak ada, dahak tidak ada, sesak dan cepat lelah ada, RR 16 kali/menit, suara napas vesikuler pada kedua lapang paru, bentuk dada simetris, retraksi dinding dada tidak ada, taktil fremitus kanan ada dan kiri ada, resonan pada kedua lapang paru, kardiomegali dengan CTR $54 \%$, cor dan paru dalam batas normal. Obat yang harus distop 1 minggu sebelum operasi Aspilet, CPG, dan Plavix. Pengkajian stimulus, stimulus fokal: ketidakseimbangan suplai dan kebutuhan oksigen miokard, iskemia miokard. Stimulus kontekstual: adanya oklusi di arteri koroner ditunjukkan hasil angiografi LM stenosis $60 \%$ di distal, LAD stenosis $75 \%$ di proksimal dan $80 \%$ di mid difusse, LCX stenosis $80 \%$ di distal dan osteal OM1 60\%, RCA CTO di proksimal dan kolateral dari LCX. Stimulus residual: pola hidup tidak sehat (merokok), sedentary lifestyle, kurang aktivitas.

Sirkulasi, pengkajian perilaku subyektif: pasien mengatakan cepat lelah saat berakivitas.
Obyektif: TD 123/69 mmHg, HR $55 \mathrm{kali} / \mathrm{menit}$, irama regular dan lemah, RR 18 kali/menit, suhu $36^{\circ} \mathrm{C}$, saturasi oksigen $100 \%$, konjungtiva ananemis, sklera anikterik, membran mukosa kering, bibir pucat, sianosis tidak ada, CRT $<2$ detik, tidak ada peninggian JVP, bunyi jantung S1S2 normal, pulsasi ekstremitas atas dan bawah kuat, gallop tidak ada, murmur tidak ada, ronchi halus ada, pulsasi arteri radialis, femoralis, dan dorsalis pedis adekuat, edema tidak ada, akral hangat, terpasang IV line. Hasil pemeriksaan laboratorium (01/03/2018): $\mathrm{Hb} 15,4 \mathrm{mg} / \mathrm{dL}(13,0-$ $16,6 \mathrm{mg} / \mathrm{dL})$, HT 43,3\% (41,3-52,1\%), leukosit $8360 / \mu \mathrm{L} \uparrow(3580-8150 / \mu \mathrm{L})$, trombosit $176 \mathrm{ribu} / \mu \mathrm{L}$ (172-359 ribu/ $\mu \mathrm{L})$. Pemeriksaan diagnostik non invasif echo (20/02/2017): ejection fraction $\mathrm{EF}$ $52 \%(53-70 \%)$ dengan pemberian Dobutamin 20/50 dan Vascon 4/50. EKG (06/03/2018): SR. Pengkajian stimulus fokal: ketidakseimbangan suplai dan kebutuhan oksigen miokard, iskemia miokard. Stimulus kontekstual: ada oklusi di koroner ditunjukkan angiografi LM stenosis $60 \%$ di distal, LAD stenosis $75 \%$ di proksimal dan $80 \%$ di mid difusse, LCX stenosis $80 \%$ di distal dan osteal OM1 $60 \%$, RCA CTO proksimal, kolateral dari LCX. Stimulus residual: pola hidup tidak sehat (merokok), sedentary lifestyle, kurang aktivitas.

Nutrisi, pengkajian perilaku subyektif: pasien mengatakan nafsu makannya berkurang. Obyektif: TB 168 cm, BB $72 \mathrm{Kg}$, IMT 25,5 > 25 $\mathrm{kg} / \mathrm{cm}^{2}$, status gizi obesitas, diet saat ini 1800 kalori/24 jam, dengan nilai gizi kalori 1860 kkal, protein 62 gr, lemak 51,75 gr, karbohidrat 288,3 gr, diet jantung, jenis makanan biasa, abdomen normal, auskultasi bowel sound LUQ, RUQ, RLQ, LLQ normal, perkusi normal, palpasi abdomen keras pada keempat kuadran abdomen, pembesaran abdomen tidak ada, pembesaran splen tidak ada. Pemeriksaan laboratorium (13/02/2018): GDS 112 $\uparrow \mathrm{mg} / \mathrm{dL}(<100 \mathrm{mg} / \mathrm{dL})$, SGOT $50 \mathrm{U} / \mathrm{L} \uparrow(0-40$ U/L), SGPT 29 U/L (0-41 U/L). Pengkajian stimulus fokal: fungsi insulin tidak efektif. Stimulus kontekstual: pola makan sebelumnya tidak terkontrol. Stimulus residual: riwayat DM tipe 2 sejak tahun 2010 tetapi tidak terkontrol. 
Eliminasi, pengkajian perilaku subyektif: tidak ada keluhan BAK dan BAB. Obyektif: BAK menggunakan DC, intake $2100 \mathrm{cc}$, output 2150, balance cairan $-50 \mathrm{cc} / 24$ jam. Frekuensi sebelum sakit 4 kali/hari dengan jumlah $1800 \mathrm{cc} / 24$ jam, warna kuning, tidak ada penggunaan obat diuretik, saat ini pasien tidak mengkonsumsi obat pencahar Laxadine. Pengkajian stimulus fokal: pasien tidak nyaman $\mathrm{BAB}$ di tempat tidur. Stimulus kontekstual: ruangan IW Bedah terbuka sekat antar pasien menggunakan gordyn (privacy kurang menurut pasien). Stimulus Residual: kebiasaan BAB 1 kali/hari.

Aktivitas dan istirahat, pengkajian perilaku subyektif: pasien mengatakan cepat lelah saat melakukan aktivitas diatas tempat tidur. Obyektif: pasien melakukan ADL dengan self care, cepat lelah saat beraktivitas, saat ini pasien tidak bedrest, dapat melakukan ROM ekstremitas atas dan bawah, bengkak pada kedua tungkai atas tidak ada, kekuatan otot segmen tangan dan kaki sama kuat. Pengkajian stimulus fokal: ketidakseimbangan suplai dan kebutuhan oksigen miokard, iskemia miokard, pasien pre tindakan CABG, pasien masih di istirahatkan untuk persiapan operasi, dianjurkan cukup isirahat dan tidur. Stimulus kontekstual: adanya oklusi di koroner CAD 3 VD. Stimulus residual: pasien belum pernah mengalami kondisi seperti sekarang ini namun pasien kooperatif terhadap pengobatan yang diberikan.

Proteksi dan perlindungan, pengkajian perilaku subyektif: pasien mengatakan nyeri pada dada sebelah kiri. Obyektif: suhu $36^{\circ} \mathrm{C}$, terpasang IV line, kulit kepala, rambut dalam keadaan bersih. Pengkajian stimulus fokal: tidak ditemukan perilaku maladaptif. Stimulus kontekstual: tidak ditemukan perilaku maladaptif. Stimulus residual: peningkatan organisme patogenik dengan leukosit $8360 / \mu \mathrm{L} \uparrow$.

Sensasi, pengkajian perilaku subyektif: pasien mengatakan nyeri dada sebelah kiri. Obyektif: nyeri dada ada, skala nyeri 3 - 5 (0-10), visus mata normal, kojungtiva anemis, sklera anikterik, refleks cahaya $+/+$, tidak ada gangguan penciuman, pengecapan manis ada, asam ada, tidak ada gangguan pendengaran. Pengkajian stimulus fokal: suplai dan kebutuhan oksigen ke miokard belum seimbang. Stimulus kontekstual: pasien pre CABG. Stimulus residual: riyawat DM tipe 2, HT, dan merokok.

Cairan dan elektrolit, pengkajian perilaku subyektif: pasien mengatakan sering haus. Obyektif: intake $2100 \mathrm{cc}$, output 2150, balance cairan $-50 \mathrm{cc} / 24$ jam. Distensi vena jugularis tidak ada, oedema anasarka tidak ada, ascites tidak ada. Pasien terpasang cairan $\mathrm{NaCL}$ 0,9\%. Hasil laboratorium (01/03/2018): ureum 41,3 mg/dL $(12,64-42,80 \mathrm{mg} / \mathrm{dL})$, creatinin $1,17 \mathrm{mg} / \mathrm{dL} \uparrow$ (0,51-0,95 mg/dL), eGFR $63 \mathrm{ml} / \mathrm{menit} / 1,73 \mathrm{~m} \downarrow$ (>90 ml/menit/1,73 m²), BUN $19 \mathrm{mg} / \mathrm{dL}(8,0-$ 23,0), Na $138 \mathrm{mmol} / \mathrm{mL}$ (135-153), Cl $99 \mathrm{mmol} / \mathrm{L}$ (98-109), Mg 2,5 mg/dL (1,6-2,4 mg/dL), K 5,2 $\mathrm{mmol} / \mathrm{L} \uparrow(3,5-5,1)$. Pengkajian stimulus fokal: injuri miokard vetrikel kanan. Stimulus kontekstual: mekanisme kompensasi akibat penurunan curah jantung. Stimulus residual: tidak adanya riwayat penurunan status cairan.

Fungsi neurologi, pengkajian perilaku subyektif: pasien mengatakan nyeri pada sebelah kiri. Obyektif: kesadaran komposmentis, status kognitif dan emosi stabil, koordinasi dan kontrol gerakan tubuh baik, fungsi sensorik dan motorik baik, paralisis tidak ada, syaraf sensori nyeri tusuk ada, suhu ada, sentuhan ada, syaraf koordinasi serebral ada, reflek patella dan achiles ada, skala nyeri VAS 2 - $3(0-10)$ di dada. Pengkajian stimulus fokal: kemampuan memori dalam keadaan baik. Stimulus kontekstual: pasien mampu mengingat tanggal penting pengobatannya oleh istrinya. Residual: tidak adanya riwayat penurunan fungsi neurologis.

Fungsi endokrin, pengkajian perilaku subyektif: Riwayat mengalami penyakit DM di sangkal pasien. Obyektif: pembesaran kelenjat tyroid tidak ada, tremor tidak ada, trias DM tidak ada, GDS 112 mg/dL $\uparrow(<100 \mathrm{mg} / \mathrm{dL})(01 / 03 / 2018)$. Pengkajian stimulus fokal: peningkatan gula darah sebagai akibat dari ketidakefektifan fungsi insulin. Stimulus kontekstual: riwayat DM sejak tahun 2010 tidak terkontrol. Stimulus residual: pola 
makan yang kurang sehat, tidak melakukan diit DM.

Mode adaptasi konsep diri, pengkajian perilaku sensasi tubuh: mengatakan cemas dengan kondisi kesehatannya. Citra tubuh: tidak pernah menyangka bahwa dirinya akan mengalami serangan jantung, karena selama ini dirinya merasa baik-baik saja dan tidak pernah mengalami keluhan. Konsistensi diri: Pasien mengatakan akan tetap berusaha tetap berobat dan akan menjaga kesehatannya. Ideal diri: ingin segera pulih dan tidak mau dirawat lagi. Moral, spiritual, dan etika diri: beragama islam, patuh melaksanakan ibadah. Sering berdoa untuk kesembuhannya. Pengkajian stimulus fokal: menderita sakit sakit jantung. Stimulus kontekstual: kurang informasi mengenai penyakit jantung yang dialaminya serta perawatannya.

Mode adaptasi fungsi peran, pengkajian perilaku sebelum sakit peran sebagai kepala keluarga dapat dijalankan dengan baik. Pasien kurang aktif di masyarakat karena waktunya terbatas. Saat di rumah sakit pasien sangat kooperatif berperan sebagai pasien. Istri selalu menunggu, hubungan dengan keluarga baik. Selama ini pasien dapat beraktivitas dengan baik. Kegiatan sehari-hari sebagai karyawan swasta. Pasien mengatakan "Selama bekerja, saya memang sering merasa stres, apalagi kalau ada pekerjaan yang seharusnya sudah selesai tapi belum juga selesai, terpaksa harus lembur kerja". Pasien juga mengatakan "mungkin saya sudah tidak bisa lagi melekukan pekerjaan seperti dulu lagi, takut aja kena serangan penyakit jantung lagi”. Pengkajian Stimulus, Stimulus fokal: ketakutan terhadap nyeri dada dan serangan jantung. Stimulus kontekstual: merasa tidak berdaya karena tidak mampu dalam melakukan beraktivitas seperti dulu lagi. Stimulus residual: tidak ada.

Mode adaptasi interdependen, pengkajian perilaku, pasien mengatakan "Kalau saya sakit lagi, saya pasti merepotkan istri dan anak-anak saya, harus bolak-balik rumah sakit. Saya tidak mau mereka seperti itu. Selama dirawat pasien ditunggu oleh istri dan anaknya secara bergantian.
Biaya berobat ditanggung oleh BPJS. Pasien juga mengatakan "Orang yang paling dekat dengan saya adalah istri saya yang selalu menemani saya di RS. Pengkajian Sttimulus fokal: tidak ada. Stimulus kontekstual: tidak ada. Stimulus residual: tidak ada.

Diagnosa keperawatan: Nyeri akut berhubungan dengan agen pencidera fisiologis dengan peningkatan beban kerja jantung dan konsumsi oksigen, penurunan aliran darah miokard, iskemia jaringan. Tujuan: Setelah implementasi keperawatan diharapkan pasien akan menunjukkan NOC: Pain Level dengan kriteria melaporkan frekuensi, durasi dan intensitas nyeri dada berkurang atau terkontrol, mendemonstrasikan penggunaan teknik penanganan nyeri, pasien tampak tenang, dan tidak tegang, tekanan darah dan frekuensi jantung dalam rentang normal. Intervensi yang diberikan untuk mengatasi diagnosa keperawatan ini adalah NIC: Pain Management yang terdiri atas regulator dan kognator, yaitu: Regulator, Aktivitas yang dilakukan yaitu: a) Pasien ditempatkan di tempat tidur dengan posisi semifowler, b) Berikan oksigen dengan nasal kanul 4 liter/menit, c) Berikan analgetik (morfin) atau anti angina (NTG) sesuai program, d) Monitor tanda-tanda vital: tekanan darah, frekuensi nadi, dan pernapasan, e) Pasang elektroda untuk monitoring jantung secara kontinu: monitor frekuensi jantung dan irama lebih sering, f) Berikan dan monitor pemberian trombolitik (sesuai program), g) Monitor adanya tanda-tanda perdarahan dan hindari melakukan pungsi vena atau arteri, h) Lakukan pengkajian yang komprehensif terhadap nyeri: progresifitas, lokasi, karakteristik, durasi, frekuensi, kualitas, intensitas dan presipitasi, eksplorasi faktor yang mempengaruhi dan memperberat nyeri, i) Catat perkembangan tingkat nyeri, j) Monitor serial EKG dan enzim jantung. Kognator, Aktivitas yang dilakukan yaitu: a) Ajarkan teknik relaksasi napas dalam, b) Diskusikan pengertian infark, tanda gejala dan faktor risiko, c) Ajarkan cara mencegah dan mengatasi nyeri dada. 
Diagnosa keperawatan: Risiko penurunan curah jantung (risiko) berhubungan dengan perubahan inotropik seperti iskemia miokard yang transient/prolonged serta efek medikasi; perubahan irama, frekuensi dan konduksi listrik jantung. Tujuan: Setelah dilakukan tindakan keperawatan, pasien akan menunjukkan NOC: Cardiac Pump Effectiveness dengan kriteria curah jantung adekuat atau optimal, ditandai dengan status hemodinamik stabil, tekanan darah, heart rate dalam batas normal, tidak ada disritmia, haluaran urin adekuat, distensi JVP tidak ada, edema tidak ada, angina tidak ada. Intervensi yang diberikan untuk mengatasi diagnosa keperawatan ini adalah NIC: Hemodynamic Regulation dan NIC: Acute Cardiac Care yang terdiri atas: 1) Regulator:

Aktivitas yang dilakukan yaitu: a) Monitor tandatanda vital, b) Catat sign and symptom dari penurunan $\mathrm{CO}, \mathrm{c}$ ) Monitor adanya disritmia, d) Monitor fungsi pace maker jika ada, e) Berikan terapi anti aritmia sesuai dengan program, f) Monitor toleransi pasien terhadap aktivitas, g) Monitor tehadap dispnea, fatique, takhipnea dan ortopnea, h) Auskultasi bunyi jantung, i) Lakukan EKG 12 lead, j) Berikan obat antikoagulan, k) Auskultasi suara paru, 1) Berikan obat inotropik positif/kontraktilitas, m) Elevasikan bagian kepala tempat tidur, n) Monitor edema perifer, distensi vena jugularis, o) Berikan obat vasodilator dan vasokonstriktor. 2) Kognator, Aktivitas yang dilakukan yaitu: a) Instruksikan pasien untuk menghindari aktivitas yang menyebabkan valsalva manuver, b) Anjurkan pasien supaya istirahat fisik dan mental selama fase akut.

Diagnosa keperawatan: Intoleransi aktivitas berhubungan dengan kelemahan umum dan ketidakseimbangan antara suplai dan kebutuhan oksigen. Tujuan: Setelah dilakukan tindakan keperawatan pasien mampu menunjukkan NOC : Activity Tolerance ditandai dengan pasien menunjukkan peningkatan toleransi terhadap aktivitas fisik, TD, frekuensi, dan irama jantung dalam batas normal, tidak ada sesak, angina, kelelahan, dan kelemahan berkurang. Intervensi yang dilakukan untuk mengatasi diagnosa ini adalah NIC: Energy Management, yaitu: 1) Regulator

Aktivitas yang dilakukan yaitu: a) Kaji aktivitas personal sehari-hari yang biasa dilakukan, b) Bantu pasien memilih aktivitas fisik sesuai kemampuan, c) Kolaborasi dengan tenaga rehabilitasi untuk menyiapkan dan mengobservasi program aktivitas sesuai dengan kebutuhan, d) Evaluasi motivasi pasien untuk meningkatkan aktivitas, e) Pantau respon kardiorespiratori saat aktivitas (takirkardia, disritmia, dispnea, diaforesis, pucat, tekanan darah, dan frekuensi respirasi), f) Pantau dan catat pola istirahat dan lamanya waktu tidur, g) Bantu kegiatan pasien secara teratur (berubah posisi, perawatan personal, ambulasi, dan transfer) h) Bantu pasien untuk merubah posisi bertahap mulai dari duduk dan berdiri. 2) Kognator,

Aktivitas yang dilakukan: a) Anjurkan untuk menghidari meningkatnya tekanan pada abdomen, seperti mengejan saat defekasi, jelaskan pola peningkatan aktivitas secara bertahap, misalnya bangun dari kursi duduk.

Diagnosa keperawatan: Kecemasan berhubungan dengan adanya nyeri dada hebat, ancaman atau perubahan status kesehatan, perubahan fungsi peran, dan lingkungan yang tidak dikenal. Tujuan: Setelah dilakukan tindakan keperawatan, pasien akan menunjukkan NOC: Anxiety Self-Control, ditandai dengan pasien tenang, kooperatif selama prosedur, tanda-tanda vital dalam batas normal, penurunan tingkat cemas, pasien dapat mendemonstrasikan kontrol cemas, tidak menunjukkan perilaku isolasi sosial. Intervensi yang dilakukan untuk mengatasi diagnosa ini adalah NIC: Anxiety Reduction, yaitu: 1) Regulator, Aktivitas yang dilakukan yaitu: a) Kaji tingkat kecemasan pasien. b) Kaji pola koping pasien dan keluarga, c) Berikan lingkungan yang kondusif dan tenang, d) Monitor respon tanda verbal dan respon noverbal kecemasan, e) Beri kesempatan pasien untuk mengungkapkan perasaannya, f) Dorong kunjungan keluarga atau orang terdekat, g) Kurangi stimulus yang menimbulkan kecemasan, h) Dukung penggunaan koping yang positif seperti berdoa. 2) Kognator 
Aktivitas yang dilakukan yaitu: a) Jelaskan semua prosedur yang dilakukan, b) Beri informasi tentang diagnosis, pengobatan dan prognosis, c) Anjurkan pasien menggunakan teknik relaksasi.

Diagnosa keperawatan: Perubahan fungsi peran berhubungan dengan krisis situasi, ketakutan terhadap nyeri akut/serangan jantung, intoleransi aktivitas. Tujuan: Setelah dilakukan tindakan keperawatan pasien akan NOC: Role Performance, ditandai dengan: melaporkan strategi untuk perubahan peran, menetapkan tujuan dan rencana yang realistis untuk rencana hidup kedepan dan menampilkan perilaku peran dalam keluarga, masyarakat dan di tempat kerja. Intervensi yang dilakukan untuk mengatasi diagnosa ini adalah NIC: Role Enhancement, yaitu: 1) Regulator, Aktivitas yang dilakukan yaitu: a) Bantu pasien untuk mengidentifikasi berbagai peran dalam hidup, b) Bantu pasien megidentifikasi peran yang biasa dalam keluarga, c) Bantu pasien untuk mengidentifikasi kekurangan peran. 2) Kognator, Aktivitas yang dilakukan yaitu: a) Ajarkan perilaku baru yang dibutuhkan oleh pasien atau orang tua untuk memenuhi suatu peran, b) Fasilitasi diskusi tentang adaptasi peran.

\section{Pembahasan}

Pembahasan terkait kasus kelolaan akan diuraikan menurut masing-masing mode dimulai dari pengkajian, menentukan diagnosis, melakukan perencanaan, melaksanakan tindakan dan melakukan evaluasi kepada pasien gangguan sistem kardiovaskular.

Tahap pengkajian, mode adaptasi fisiologis, nyeri akut. Masalah keperawatan nyeri yang dialami Tn. MT terjadi karena agen pencidera fisiologis, rasa nyeri timbul terutama saat menarik napas dan batuk untuk mengeluarkan sputum. Durasi nyeri tidak terlalu lama, tetapi ekspresi wajah pasien yang tampak meringis menandakan bahwa nyeri yang dirasakan masih sangat mengganggu. Rentang nyeri 2-3 dari rentang nyeri 0-10. Aspek mode fisiologis yang dilakukan seorang perawat terhadap masalah nyeri merupakan kegiatan non farmakologi dan farmakologi, khususnya pada pasien Tn. MT diberikan kompres dingin pada area yang merasa nyeri dengan meletakkan gel pack, selain itu latih pasien untuk relaksasi dengan menarik napas dalam. Namun apabila tindakan tersebut kurang efektif maka perawat dapat melakukan kolaborasi untuk diberikan terapi. Nyeri dada yang dialami oleh Tn. MT disebabkan oleh stimulus fokal ketidakseimbangan suplai dan kebutuhan oksigen miokard akibat oklusi total pada arteri koroner LAD. Oklusi arteri koroner menyebabkan penurunan perfusi vaskuler miokard dimana dalam waktu 10 detik saja, sel-sel miokard dapat mengalami hipoksia dan jika terus berlangsung dalam waktu beberapa menit, sel miokard akan kehilangan oksigen dan glukosa yang akan memicu terjadinya metabolisme anaerob. Metabolisme anaerob berlangsung dan terjadi asam akumulasi laktat. Asam laktat mengiritasi serat saraf miokard dan mentransmisikan pesan nyeri ke saraf-saraf miokard dan serabut-serabut saraf toraks posterior bagian atas.

Perangsangan saraf memunculkan sensasi rasa nyeri dada di bagian kiri dan dapat menyebar ke bahu dan lengan kiri. Kondisi iskemik ini dapat pulih kembali jika berlangsung hanya sekitar 20 menit, dengan pemulihan aliran darah, metabolisme anaerobik terhenti dan sel-sel miokard pulih kembali (Lewis et al, 2011; Smith \& Whitwam, 2006). Nyeri dada yang dirasakan oleh Tn. MT berlangsung lebih dari 20 menit, hal ini mengindikasikan tidak adanya proses pemulihan iskemik yang terjadi dalam waktu 20 menit dan mengakibatkan terjadinya nekrosis atau infark pada miokard otot jantung. Tn. MT dibaringkan di tempat tidur dengan posisi semifowler dan dianjurkan untuk tenang, kemudian pasien diberi oksigen dengan nasal kanul sebanyak 3 liter/menit. Pemberian posisi tidur akan berfungsi untuk meminimalkan aktivitas fisik dan metabolisme sehingga menurunkan kebutuhan oksigen untuk meminimalkan risiko cidera dan nekrosis jaringan miokard otot jantung, sedangkan pemberian oksigen bertujuan untuk meningkatkan ketersediaan oksigen dan pemulihan miokard yang 
mengalami iskemia namun ternyata pemberian oksigen ini sebaiknya disesuaikan dengan saturasi oksigen pasien (Doenges et al, 2010).

Risiko penurunan curah jantung yang dialami oleh Tn. MT diakibatkan ole injuri miokard dan perubahan kontraktilitas miokard. Hal ini ditandai dengan tekanan darah yang cenderung rendah 108/75 mmHg, sesak napas, hasil ekokardiografi EF 52\%, akinetik apikal luas, anterior dan anteroseptal serta hipokinetik di mid septal, EKG acute anterior extensive dan RV infark. Diagnosa ini ditegakkan setelah dilakukan pengkajian lebih lanjut pada mode fisiologis khususnya pada mode oksigenasi. Diagnosa ini ditegakkan pada hari perawatan ke-2 tanggal 6 Maret 2018. Kondisi hemodinamik sesudah infark miokard bervariasi namun curah jantung dapat menurun. Meningkatnya frekuensi jantung biasanya tidak berlangsung terus menerus kecuali jika terjadi depresi miokard yang hebat. Tekanan darah merupakan fungsi interaksi antar depresi miokard dan refleks otonom. Respon otonom terhadap infark miokard tidak selalu merupakan proses bantuan simpatis terhadap sirkulasi yang mengalami gangguan. Perangsangan ganglion parasimpatis dapat mengganggu hemodinamik, menurunkan frekuensi jantung dan tekanan darah, sebaliknya mempengaruhi curah jantung dan perfusi perifer (Price \& Wilson, 2012). Intervensi yang dilakukan pada Tn. MT adalah hemodynamic regulation dan acute cardiac care, yaitu memonitor TTV, mencatat tanda dan gejala dari penurunan $\mathrm{CO}$, memonitor adanya disritmia, memonitor dispnea, fatique, takipnea dan ortopnea, auskultasi bunyi jantung dan paru, melakukan EKG 12 lead, memberikan obat antikoagulan, memberikan inotropik positif, mengelevasikan bagian kepala tempat tidur, memonitor edema perifer, distensi vena jugularis.

Dalam waktu 10-14 hari setelah mengalami infark miokard, jaringan parut yang baru terbentuk masih sangat lemah. Otot jantung sangat rentan terhadap peningkatan tekanan selama jangka waktu ini akibat ketidakstabilan bagian dinding jantung yang mengalami proses penyembuhan. Peningkatan aktivitas dapat dimulai pada kondisi seperti ini. Setelah 6 minggu mengalami infark, jaringan parut telah menggantikan jaringan nekrotik. Pada saat tersebut, area yang mengalami injuri bisa dianggap telah pulih. Area jaringan parut biasanya kurang kompatibel dibandingkan dengan jaringan sekitarnya. Kondisi ini dapat menimbulkan disritmia atau gagal jantung (Lewis et al, 2011). Tn. MT baru dapat beradaptasi dengan level kompensatori terhadap penurunan curah jantung pada hari kedua dengan menunjukkan kriteria status hemodinamik stabil: (EF 52\%, CO 3,5 liter/menit, SV $45 \mathrm{ml}$ ), tekanan darah 100/80 $\mathrm{mmHg}$ dan heart rate $74 \mathrm{x} / \mathrm{menit}$, tidak ada disritmia, haluaran urine adekuat $\pm 3 \mathrm{cc} / \mathrm{kg} / \mathrm{jam}$, tidak ada distensi vena jugularis, tidak terdapat edema, tidak ada angina, bunyi napas tambahan ronchi tidak ada. Kemudian pasien pindah ke IW Bedah dengan kondisi curah jantung yang terus membaik hingga pasien pulang.

Intoleransi aktivitas, merupakan diagnosa keperawatan yang menitikberatkan respon tubuh yang tidak mampu bergerak karena tubuh tidak mampu memproduksi energi yang cukup untuk aktivitas sehari-hari (Herdman, 2012). Gangguan kontraktilitas jantung, darah yang dipompa ke seluruh tubuh yang membawa nutrisi dan oksigen persentasenya menurun. Hal ini berdampak pada suplai ke jaringan, sehingga terjadi hambatan pada proses metabolisme untuk menghasilkan energi. Kondisi inilah yang paling sering ditemukan pada pasien gangguan kardiovaskular yang menimbulkan dampak yang beragam dari tiap-tiap pasien, diantaranya yang nantinya membawa perubahan dalam perawatan diri. Pemenuhan kebutuhan perawatan diri tidak hanya dilakukan pada saat pasien dirawat, namun bagaimana pasien ketika melakukan perawatan diri di rumah juga menjadi tanggung jawab yang besar bagi seorang perawat (Dalal, Doherty, \& Taylor 2012).

Panduan SDKI (2016) menyebutkan bahwa tanda dan gejala mayor objektif untuk diagnosa intoleransi aktivitas ini adalah 
peningkatan frekuensi jantung $>20 \%$ dari kondisi istirahat, sedangkan untuk peningkatan tekanan darah $>20 \%$ merupakan kriteria minor sehingga hal ini sesuai dengan kondisi yang ditemukan di klinis. Manajemen energi merupakan upaya pengaturan energi yang digunakan untuk menangani atau mencegah kelelahan dan mengoptimalkan fungsi (Bulechek, 2013). Tindakan yang dapat dilakukan seperti peningkatan latihan yang bertujuan untuk meningkatkan kebugaran, manajemen nutrisi untuk menyediakan suplai nutrisi yang diperlukan tubuh untuk membentuk energi, terapi oksigen jika pasien memerlukan bantuan suplai, bantuan dalam pemenuhan ADL, dan meningkatkan kualitas serta kuantitas istirahat tidur. Rehabilitasi kardiovaskular merupakan upaya yang dapat dilakukan dalam rangka peningkatan fungsi aktivitas yang paling maksimum pada pasien yang telah mengalami episode gangguan jantung yang terjadi karena adanya ketidakseimbangan antara pemenuhan suplai oksigen ke otot jantung dan kebutuhannya (Bulechek, 2013).

Mode adaptasi konsep diri: cemas. Kecemasan didefinisikan sebagai suatu keresahan, perasaan ketidaknyamanan yang penyebabnya tidak spesifik oleh individu, rasa khawatir yang ditimbulkan oleh antisipasi terhadap yang membahayakan. Cemas yaitu tanda yang memberi peringatan adanya bahaya yang bisa terjadi dan memampukan seseorang untuk melakukan pengukuran dalam mengatasi sesuatu yang mengancam (Herdman, 2012). Tn. MT mengalami kecemasan karena ketakutan akibat perubahan status kesehatan yang dialaminya dan mengatakan merasa khawatir dengan kondisi tidak pasti dari penyakitnya, keluhan nyeri hebat yang dirasakannya adalah keluhan yang pertama kali. Tn. MT tidak pernah menyangka ternyata keluhan sakit dada yang dirasakannya itu serangan jantung, karena selama ini merasa dirinya baik-baik saja.

Intervensi yang diberikan untuk mengatasi kecemasan yang dialami Tn. MT adalah dengan memberikan lingkungan yang tenang untuk mengurangi stimulus dari lingkungan. Selain itu, terkadang stimulus tidak berasal dari lingkungan tetapi dari tenaga kesehatan khususnya perawat. Disadari atau tidak, perilaku perawat yang tergesagesa dan terburu-buru saat berada di sekitar pasien dipersepsikan pasien sebagai adanya sesuatu yang tidak beres yang sedang terjadi dan sangat sering persepsi ketidakberesan dikaitkan dengan diri pasien dan menimbulkan kecemasan pada pasien. Sehingga perawat perlu untuk selalu menyadari dan mempertahankan perilaku yang tidak tergesagesa serta terburu-buru dan melakukan interaksi ke pasien dengan sikap tenang.

Intervensi lain yang dapat dilakukan untuk menurunkan kecemasan Tn. MT adalah dengan memberikan dukungan kepada pasien dan menggunakan mekanisme koping berdoa, membaca Al-Quran dan memperbanyak dzikir. Dari pengamatan perawat, mekanisme koping dengan pendekatan spiritual seperti ini memberikan rasa nyaman, kedekatan terhadap Tuhan dan doa-doa yang disampaikan memberikan harapan-harapan positif dan meningkatkan kepercayaan diri dalam menghadapi masalah serta kepasrahan menjalani penyakit. Hudak \& Gallo (2012) berpendapat bahwa mekanisme koping dengan pendekatan religius-spiritual meningkatkan kesadaran terhadap adanya pengaruh dan kekuatan luar yang lebih besar serta meningkatkan perasaan terhubung dengan sumber kekuatan tersebut sehingga menimbulkan perasaan tenang bagi pasien. Tn. MT dapat beradatapsi secara kompensatori terhadap kecemasan yang dialaminya. Pasien mulai dapat beradaptasi dan menunjukkan pengendalian diri terhadap cemas pada hari kedua. Tn. MT tampak lebih tenang dan dapat berinteraksi atau berkomunikasi dengan perawat tanpa ekspresi cemas dan tegang. Saat pasien di ruang perawatan, sudah terjadi penurunan skor cemas menjadi 2 (VAS 0-10) yang awalnya 3 pada hari 1 pre operasi.

Sejalan dengan hal tersebut Perry dan Potter (2010) menyatakan bahwa ansietas/ cemas meningkatkan persepsi terhadap nyeri dan nyeri bisa menyebabkan seseorang cemas. Seseorang yang mengalami kecemasan akan menunjukan perilaku penurunan produktifi tas, gelisah, 
insomnia, kesedihan yang mendalam, ketakutan, perasaan ketidakberdayaan, bingung, khawatir, rasa tidak percaya diri. Secara fisiologis juga akan nampak ketegangan di wajah, suara bergetar, peningkatan ketegangan, hal ini akan berdampak kepada penurunan kualitas hidup penderitanya (Sovodka 2010). Penelitian lain yang dilakukan oleh Cully, Phillips, Kunik, Stanley, \& Deswall (2010) tentang predicting kualitas hidup in veterans with heart failure: role of disease severity, depression and comorbid anxiety menunjukkan bahwa depresi berhubungan dengan penurunan skor kualitas hidup pasien. Bahkan lebih dari itu, menurut McGowan (2011) depresi tidak hanya menurunkan kualitas hidup pasien pasien tetapi juga secara signifikan meningkatkan risiko kematian bagi pasien dengan CAD.

Intervensi yang dilakukan untuk mengadaptasikan pasien dengan perubahan penampilan peran yang dialaminya adalah dengan membantu pasien mengidentifikasi berbagai peran dalam hidup dan mengidentifikasi kekurangan peran dan berdiskusi tentang adaptasi peran yang bisa dilakukan. Tn. MT adalah seorang suami dan kepala rumah tangga yang harus bekerja untuk membiayai kehidupan sehari-hari keluarganya. Dalam mendiskusikan strategi dan adaptasi peran baru bagi pasien diperlukan keterlibatan keluarga terutama istri dan anak untuk membuat kesepakatan peran baru yang akan dijalani pasien. Tidak jarang memunculkan konflik dalam keluarga karena tidak adanya kesepakatan tentang harapan dan keinginan peran pasien dari awal. Kesepakatan yang dibuat keluarga akan memunculkan pengertian keluarga akan perubahan peran yang dijalani pasien. Selama pasien menjalani fase pemulihan, Pasien dianjurkan untuk sementara waktu untuk beristirahat dan menjalankan perubahan perannya dengan tidak bekerja terlebih dahulu sampai kemudian kondisinya betul-betul pulih dan siap untuk bekerja serta aktif kembali. Tn. MT dapat beradatapsi secara kompensatori terhadap perubahan penampilan peran yang dialaminya. Pada hari rawat ke-2, pasien mengungkapkan rencana-rencana terkait perubahan peran yang dialaminya, seperti akan membatasi pekerjaan sesuai dengan batas kemampuannya dan tidak akan memaksakan diri dalam bekerja.

Mode adaptasi fungsi peran, penampilan peran tidak efektif Tn MT diartikan sebagai pola perilaku dan pengekspresian diri yang tidak sesuai dengan konteks lingkungan dan harapan (Herdman, 2012). Penampilan peran tidak efektif yang dialami oleh Tn. MT disebabkan oleh status kesehatan saat ini yang tidak memungkinkan pasien bekerja seperti dulu. Setiap harinya pasien bekerja sebagai koordinator proyek yang harus bekerja di luar ruangan yang menguras banyak tenaga. Pasien khawatir tidak dapat menjalankan perannya semula karena ketakutan mendapatkan serangan jantung lagi.Terkait perubahan peran yang terjadi pada pasien miokard infark merupakan suatu pengacauan yang menakutkan dan tidak diinginkan yang mengganggu rasa kontrol pasien terhadap kehidupannya. Pasien mengalami suatu 'biographical disruption', yaitu suatu perubahan yang tidak terhindarkan dan dipaksakan dalam kehidupannya. Perubahan yang dialami akibat infark miokard membuat pasien tidak dapat bekerja seperti semula. Intervensi yang dilakukan untuk mengadaptasikan pasien dengan perubahan penampilan peran yang dialaminya adalah dengan membantu pasien mengidentifikasi berbagai peran dalam hidup dan mengidentifikasi kekurangan peran dan berdiskusi tentang adaptasi peran yang bisa dilakukan.

Tn. MT adalah seorang suami dan kepala rumah tangga yang harus bekerja untuk membiayai kehidupan sehari-hari keluarganya. Apalagi saat ini anak Tn. MT sedang kuliah dan butuh biaya yang relatif banyak. Dalam mendiskusikan strategi dan adaptasi peran baru bagi pasien diperlukan keterlibatan langsung keluarga terutama dalam hali ini adalah istri dan anak untuk membuat kesepakatan peran baru yang dijalani pasien. Tidak jarang memunculkan konflik dalam keluarga karena tidak adanya kesepakatan tentang harapan dan keinginan peran pasien dari awal. Kesepakatan yang dibuat keluarga memunculkan pengertian keluarga terhadap perubahan peran yang dijalani 
pasien. Selama pasien menjalani fase pemulihan. Pasien dianjurkan untuk sementara waktu beristirahat dan menjalankan perubahan perannya dengan tidak bekerja dulu sampai kemudian kondisinya betul-betul pulih dan siap untuk bekerja serta aktif kembali. Tn. MT dapat beradaptasi secara kompensatori terhadap perubahan penampilan peran yang dialaminya. Pada hari rawat ke-2, pasien mengungkapkan rencanarencana terkait perubahan peran yang dialaminya, seperti membatasi pekerjaan sesuai dengan batas kemampuannya dan tidak memaksakan diri dalam bekerja.

Hasil penelitian sebelumnya yang dilakukan oleh Alligood \& Tomey (2014) menyatakan bahwa gangguan mode fungsi peran yang sering terjadi pada pasien dengan gangguan sistem kardiovaskular adalah perubahan penampilan peran, sehingga diagnosa utama pada pasien gangguan kardiovaskular adalah penampilan peran tidak efektif. Penampilan peran tidak efektif ini paling banyak terjadi karena ketidakberdayaan. Penyakit jantung yang diderita membuat pasien tidak dapat lagi berperan dan berfungsi seperti yang diharapkan baik yang diharapkan oleh pasien sendiri maupun keluarga tempat kerja dan masyarakat tempat tinggal pasien. Perawat harus membantu pasien untuk membuat strategi perubahan yang dapat dijalani pasien sesuai dengan kondisinya, seperti mengurangi intensitas. Dalam kondisi ketidakberdayaan, pasien memerlukan support system yang baik terutama dari keluarga. Sehingga perawat dapat memfasilitasi pasien dan keluarga untuk menyusun rencana asuhan keperawatan secara bersama-sama tentang perubahan dan strategi penampilan peran yang baru bagi pasien.

\section{Kesimpulan}

*Peran sebagai pemberi asuhan keperawatan dapat dilakukan dengan menggunakan pendekatan Model Adaptasi Roy pada berbagai kasus dengan mengeksplorasi masalah asuhan keperawatan dimulai dari pengkajian, menentukan diagnosis, melakukan perencanaan, melaksanakan tindakan dan melakukan evaluasi kepada pasien gangguan sistem kardiovaskular. Adaptasi yang terjadi pada pasien kelompok kasus sindroma koroner akut tanpa komplikasi, rata-rata dapat mencapai adaptasi tingkat integrated.

*Proses adaptasi pasien dan keluarga dapat tercapai secara compensatory atau integrated setelah pemahaman tentang penyakitnya meningkat/lebih baik dari sebelumnya.

*Teori model ini memungkinkan perawat memberikan asuhan keperawatan dengan lebih komprehensif untuk membantu pasien meningkatkan kemampuan adaptasinya terhadap perubahan lingkungan baik internal maupun eksternal yang mengancam integritas fisik dan psikologis pasien.

\section{Saran}

*Teori Keperawatan Model Adaptasi Roy dapat diaplikasikan dalam tatanan klinik saat dalam memberikan asuhan keperawatan pada pasien dengan gangguan sistem kardiovaskular menggunakan format yang disesuaikan dengan format yang ada di rumah sakit.

*Perlu diadakan pertemuan untuk menyamakan persepsi tentang aplikasi teori Keperawatan Model Adaptasi Roy.

\section{Daftar Pustaka}

Alligood, M R., \& Tomey, M. A. (2014). Nursing Theory Utilization \& Application. Third Edition. Mosby : St. Louis. Missouri.

American Heart Association (AHA). (2017). Cardiovascular Disease and Diabetes http://www.org/HEARTORG/Conditions/Diabetes/wh yDiabetesMatters/Cardiovascular-Disease-Diabetes UCM 313865 Article.jsp.

Bash, E. (2015). Biopsycosocial Spiritual Factors Impacting African American Patient's Cardiac Rehabilitation Refferal and Participation. 1(March), 1-18. https://doi.org/10.1017/CBO9781107415324.

Bulechek. (2013). Nursing Interventions Classification (NIC). Jakarta: EGC.

Christensen, P. J., \& Kenney, J. W. (2009). Proses Keperawatan, Aplikasi Model Konseptual (Terj. dari Nursing Process: Application of Conceptual Models. 4th Ed). Jakarta: Penerbit Buku Kedokteran EGC. 
Cully, J.A., Phillips, L.L., Kunik, M.E., Stanley, M.A., \& Deswal, A. (2010). Predicting quality of life in veterans with heart failure: the role of disease severity, depression, and comorbid anxiety. Behavioral medicine, 36, 70-76.

Dalal, H. M., Doherty, P., \& Taylor, R. S. (2012). Cardiac Rehabilitation. American Family Physician, 80(9), 955. http://doi.org/10.1136/bmj.h5000.

Doenges, M E dkk. (2010). Rencana Asuhan Keperawatan: pedoman untuk perencanaan dan pendokumentasian perawatan pasien. Jakarta: EGC.34-39. http://doi.org/10.1016/j.ijcard.2015.08.155.

Herdman, T Heather. 2012. Diagnose Keperawatan: Definisi dan Klasifikasi 2012-2014. Dialihbahasakan oleh Made Sumarwati dan Nike Budhi Subekti. Barrarah Bariid, Monica Ester, dan Wuri Praptiani (ed). Jakarta: EGC.

Hudak \& Gallo, 2012. Keperawatan Kritis: Pendekatan Asuhan Holistic Vol 1. Jakarta: EGC.

Ignatavicius, D.D. \& Workman, M.L. (2010). Medical Surgical Nursing: Critical Thinking for Collaborative Care. Sixth Edition. Volume 1. USA: Saunders Elsevier.

Lewis, S. L., Heitkemper, M. M., \& Dirksen, S. R., O'Brien, P. G., \& Bucher, L.(2011). Medical surgical nursing: Assesment and management of clinical Problems (Vol. 2, 8th Ed). St. Louis: Mosby Elsevier.

McGowan, D. (2011). The impact of depression on the pathogenesis of heart failure. British Journal of Cardiac Nursing, 6 (1), 19-25

Penelitian, B., Pengembangan, D. A. N., \& Pengantar, K. (2018). Riset Kesehatan Dasar.

Perry, A. G; Potter , P. A;. (2007). Fundamental of Nursing (6th ed.). Italy: Elsevier Health Science Division.

Price, S. A. \& Wilson, L. M. (2012). Pathophysiology: Clinical concept of desease processes. St. Louis: Elsevier Science

Roy, S. C., \& Andrews, H. (2009). The Roy Adaptation Model. New Jersey: Pearson Education.

SDKI, DPP PPNI. (2016). Standar Diagnosis Keperawatan Indonesia: definisi dan indikator diagnostik (edisi 1): Jakarta: DPP PPNI.

Sovodka, P. (2010). Secret of Hypnotherapy. Jogjakarta: FlashBooks. 